\title{
The Principal Jurisdictional Maxims in International Criminal Law: Opting the Uncontested and the Feasible One
}

\author{
Alemseged Dejenie \\ College of Law, Dire-Dawa University, Dire-Dawa, Ethiopia \\ Email: Alemsegeddejenie460@gmail.com
}

How to cite this paper: Dejenie, A. (2019). The Principal Jurisdictional Maxims in International Criminal Law: Opting the Uncontested and the Feasible One. Beijing Law Review, 10, 1012-1019. https://doi.org/10.4236/blr.2019.104054

Received: July 25, 2019

Accepted: September 16, 2019

Published: September 19, 2019

Copyright ( 2019 by author(s) and Scientific Research Publishing Inc. This work is licensed under the Creative Commons Attribution International License (CC BY 4.0).

http://creativecommons.org/licenses/by/4.0/

\begin{abstract}
This article scrutinizes the prevailing jurisdictional principles of international criminal law and identifies the most feasible once which would assist the International Criminal Court in achieving its core objectives. In so doing in-depth investigations of the contemporary constitutional and criminal legislations of Ethiopia in tandem with international laws has been made. The article argues that the Principle of Complementarity has the possible way outs for the pitfalls of the other competing maxims by giving deference to national-level prosecutions under most circumstances.
\end{abstract}

\section{Keywords}

Complementarity, Primacy, Concurrency, Jurisdiction, Ne bis in idem

\section{Introduction}

The principle of complementarity is among the grand governing maxims upon which international criminal court operates. The principle is all about complementing the lacunas which have left by the principal body for various reasons to ensure the proper disposition of justice while the sovereignty of the States is not at stake.

However, the principle of primacy jurisdiction is pro tanto exclusive jurisdiction. Insofar as the one sovereign State has jurisdiction to preside over a crime which has committed in its territory, it excludes other States from adjudicating the matter or if other States have already presided over the case based on the principle of subsidiary jurisdiction, the principle of primacy jurisdiction does not preclude the State with primacy jurisdiction from presiding on the case irrespective of the principle of ne bis in idem even though the nature and com- 
mission of the crime are affecting the interest of the international community at large.

The principle of Concurrence Jurisdiction presupposes the existence of two Courts which are presiding over the same case most probably at the same time. The reason for concurrent jurisdiction is a moral proposition. The nature and the commissions of some crimes would have transnational effects. As a result in addition to national adjudications of the crime, it should be condemned by an international entity. However, concurrent jurisdiction has complex shortcomings such as problems in the distribution of suspects.

To overcome the aforementioned pitfalls, complementary jurisdiction which represents the idea that states, rather than the International Criminal Court, shall have priority in proceeding with cases within their jurisdiction came up with the possible way outs by giving deference to national-level prosecutions under most circumstances.

\section{A Glimpse of the Principle of Complementarity}

The principle of Complementarity is one of the main governing principles upon which the operation of the International Criminal Court is premised (El Zeidy, 2002). It can be defined as a functional principle aimed at granting jurisdiction to a subsidiary body when the main body fails to exercise its primary jurisdiction (Philippe, 2006). This is nothing other than a principle of priority among several bodies able to exercise jurisdiction (Brown, 1998).

\subsection{The Principle of Primacy vs. Complementarity Jurisdiction}

The traditional notion of State sovereignty has empowered States to assume primacy jurisdiction for punishing crimes, even in cases where the "international character" of the crimes urged the creation of international mechanisms for repression ${ }^{1}$. Even if the crimes committed are of a type that affects the international community as a whole, States are often hesitant to have their nationals tried by an international judicial organ ${ }^{2}$.

Primacy jurisdiction is pro tanto exclusive jurisdiction; (Jaffe, 1964) insofar as the one State has jurisdiction it excludes other States from presiding on the case or if other States has already presided over the case the principle of primacy jurisdiction does not preclude the State with primacy jurisdiction from adjudicating the matter irrespective of the principle of ne bis in idem.

For a better understanding of the matter at hand let me discuss these jurisdictional maxims from Ethiopian Criminal Law Perspective.

According to Article 11, 12, 13, 14 and 15(2) of Federal Democratic Republic of Ethiopia (FDRE) Criminal Code, Ethiopian Courts shall have primacy jurisdiction when the crime has been committed on Ethiopian territory, crimes committed against Ethiopia outside its territory, crimes committed abroad by an 
Ethiopian enjoying immunity and crimes committed in a Foreign Country by a member of the defense forces against International law and specifically military crimes as defined in Article 269-322. The theoretical justifications behind this principle are the principle of territoriality, the principle of quasi territoriality, the principle of active personality or nationality principle and the principle of passive personality principle (Glory \& Zegeye, 2009).

The effect of the principle would go to the extent of banning other States from having complementary jurisdiction or empowering Ethiopian Courts to try a criminal even though he may also be or has already been tried in a foreign country for the same offense ${ }^{3}$. As a result, the principle of primacy jurisdiction would broad either the possibility of impunity or double jeopardy of the accused.

\subsubsection{Example One}

A crime has been committed in Ethiopia territory while the suspect has fled into abroad. Despite stiff negotiation between Ethiopia and the host state, his extradition has not been obtained. Detrimental to the proper disposition of justice the host state is not willing or able to preside over the matter in accordance with article 12 of the FDRE Criminal Code and the notion of subsidiary jurisdiction has not been incorporated in the criminal law of the host state. Then in this instant, the suspect can easily escape criminal punishment without facing justice.

\subsubsection{Example Two}

A crime has been committed abroad against Ethiopian national interests (Article 13 of FDRE Criminal Code) however; his extradition has not been obtained. The country under which the crime has committed tried and convicted the suspect and the criminal served his prison under the law of the place of the commission of the crime. Later the criminal found in Ethiopian territory and the Ethiopian courts preside over the same case.

The criminal would be subject to double punishment since conviction or acquittals of the criminal in abroad cannot bar prosecution and trial from being conducted in Ethiopia as per article 16 of FDRE Criminal Code.

The principle of primacy jurisdiction didn't take into account some crimes the nature and commission of which could affect the interest of the International community as a whole. The principle has no leeway to narrow the possibility of impunity under which the transgressors of International criminal law may go unpunished. However, certain crimes are so harmful to international interests that states are entitled and even obliged to bring proceedings against the perpetrator, regardless of the location of the crime and the nationality of the perpetrator or the victim ${ }^{4}$.

These pitfalls of the primacy jurisdiction which has historical antecedent from the traditional notions of International legal order had to be overcome through the Principle of Complementarity.

${ }^{3}$ Id, P 130.

${ }^{4}$ Philippe, Supra Note 2, P. 377. 
The principle of Complementarity in International criminal law requires the existence of both National and International criminal justice systems functioning in a subsidiary manner for curbing crimes of international law ${ }^{5}$ when the former fails to do so, the latter intervenes and ensures that the perpetrators do not go unpunished ${ }^{6}$.

The principle of Complementarity is based on a compromise between respect for the principle of state sovereignty and respect for the principle of universal jurisdiction, in other words on acceptance by the former that those who have committed international crimes may be punished through the creation and recognition of international criminal bodies ${ }^{7}$.

Complementarity is a principle which represents the idea that states, rather than the International Criminal Court, will have priority in proceeding with cases within their jurisdiction (Carter, 2010).

In tandem with Complementarity principle, the FDRE Criminal code has enshrined a subsidiary jurisdictional clause to preside and try cases when a person who has committed outside Ethiopia a crime against international law or an international crime specified in Ethiopian legislation or an international treaty or a convention to which Ethiopia has adhered is found in Ethiopian territory (Article 17(1) of FDRE Criminal Code). However, the criminal cannot be tried and sentenced in Ethiopia if he was regularly acquitted or discharged for the same act in a foreign country (Article 20(1)).

To have an in-depth understanding of the Principles of Primacy and Complementarity let me discuss Adjudicatory devolution of power over federal matters between the two tiers of Governments under the FDRE Constitution.

Similarly, as legislative and executive power, the judiciary power in Ethiopian federation has been divided between the Federal and State Courts (Article 79(1) of the FDRE Constitution).

According to Article 3 of the Federal Courts Proclamation No. 25/1996, Federal Courts shall have primacy jurisdiction to preside over:

1) Cases arising under the Constitution, Federal Laws and International Treaties;

2) Parties specified in Federal Laws;

3) Places specified in the Constitution or Federal Laws.

However, due to the inaccessibility of Federal Courts in every Regional States of the Federation, the Federal Courts may unable to pursue their primacy jurisdictions. However, failure to exercise the primacy jurisdictions of Federal Courts would prejudice the right to access to justice of the peoples. To overcome the potential obstacles in the speedy disposition of justice, the FDRE Constitution came up with seemingly complementary adjudicatory jurisdiction of Regional Courts over federal matters.

According to Article 78(2) of FDRE Constitution, the jurisdictions of the Fed${ }^{5}$ Id, P. 380.

${ }^{6}$ Zeidy, Supra Note 1, P. 870.

${ }^{7}$ Philippe, Supra Note 2, Pp. 380-381. 
eral High Court and the First Instance Court may be delegated to the State Supreme Court and the State High Court respectively to fill the gaps which have left by the absence of Federal Courts in some Regional States.

Last but not least, for a better understanding of the matter let me add legislative devolution of power over penal laws under the FDRE Constitution.

The constitutional allocation of legislative power is defined on the basis of three categories, namely exclusive powers (of the federal government and/or of the states), concurrent powers and reserve powers (Fisha, 2009). In the US, a Swiss, German and Ethiopian federation the Federal Government is granted enumerated powers 8 .

According to Article 55(5) of FDRE Constitution, the House of Peoples Representatives (HPR) has a primacy jurisdiction to enact penal law which should be applicable throughout the Country. However, the dynamic and diversified nature of the crimes added with the heterogeneous attributions of the societies, the HPR may fail to address every crime in the Country.

Intending to curtail the possible impunity of the offenders due to the grand maxim of criminal law that is the principle of legality, the Constitution of the FDRE in the same Provision has empowered the State Councils to enact penal laws which are not addressed by the HPR.

As the writer try to discuss before the principle of Complementarity is a functional principle aimed at granting jurisdiction to a subsidiary body when the main body fails to exercise its primacy jurisdiction ${ }^{9}$. Once the HPR has failed its primacy jurisdiction of enacting penal laws for various reasons as the writer try to mention before, the Constitutional Complementarity legislative jurisdiction of State Councils over penal matters shall be stepping in.

The Constitutional Complementary legislative jurisdiction of State Councils will have significant roles in prohibiting some crimes which are prevalent in a specific regional state, adhering with the principle of legality and curtailing the possibility of impunity.

Before the adoption of Rome Statute, how the relationship between National and International Justice System could be regulated was a fundamental problem facing the drafters of the Statute of the International Criminal Court ${ }^{10}$ since defining the concise nature of such interface was both politically sensitive and legally complex.

Some argue that the relation between National and International Justice System should be based on "a cooperative and healthy synergy" (Newton, 2010). In so doing a case is inadmissible before the International Criminal Court if a state with primacy jurisdiction is willing and able to proceed with the investigation, prosecution, and trial or if the accused was already tried for the conduct and a further prosecution is now barred under the ne bis in idem provision which is among the basic principle of Rome Statute. The prior adjudication triggers the ${ }^{8}$ Ibid.

${ }^{9}$ Philippe, Supra Note 2, P. 380

${ }^{10}$ Zeidy, Supra Note 1, P.890. 
principle of ne bis in idem ${ }^{11}$. The definitions chosen for ne bis in idem in the International Criminal Court statute foster the priority of States in initially prosecuting crimes, give states great leeway to prosecute after an International Criminal Court prosecution and greatly limit the ability of the Court to prosecute after a state adjudication of the facts ${ }^{12}$. The International Criminal Court Statute ne bis in idem provisions are protective, rather than preemptive, of state prerogatives. ${ }^{13}$

\subsection{The Principle of Concurrence vs. Complementarity Jurisdiction}

The principle of Concurrence Jurisdiction presupposes the existence of dual trials which are presiding over the same case. Under the negotiations over the terms for establishing the International Criminal Tribunal for Rwanda (ICTR), Rwanda objected to several provisions to retain some adjudicatory power in parallel to ICTR proceeding. Rwanda took exception to the period over which the ICTR would have jurisdiction (Morris, 1997). According to the ICTR Statute then being drafted, only crimes committed between January 1 and December 31, 1994, would come within the jurisdiction of the ICTR.

The rationale for stratified-concurrent jurisdiction is essentially a moral proposition: those crimes of a certain magnitude and a certain nature should be condemned by an international entity, a "voice of humanity"14. However, Concurrent jurisdiction raises complex questions regarding cooperation in investigations and sharing of evidence, difficulties concerning the confidentiality of evidence, witness protection, due process standards, the need to avoid any appearance of partiality of the international tribunal and problems in the distribution of suspects raise delicate questions ${ }^{15}$. The question of appropriate distribution of defendants has been the cause of uncertainty and, at times, of tension between national governments and the ICTR ${ }^{16}$.

The ICTR and the Government of Rwanda have sought to obtain custody of the same suspect which has led a contention between themselves. For instance, Froduard Karamira became the object of a brief "tug of war" between the ICTR and the government of Rwanda. Karamira is believed to have been among the leaders of the Rwandan genocide.

To overcome the aforementioned shortcomings the essences of Complementary jurisdiction which represents the idea that states, rather than the International Criminal Court, will have priority in proceeding with cases within their jurisdiction ${ }^{17}$ came up with the possible way outs by giving deference to national-level prosecutions under most circumstances.

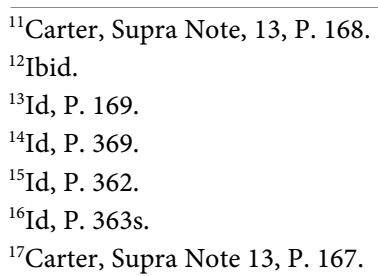




\section{Concluding Remarks}

Though the study at hand is too concise, the writer can conclude the following points.

The principle of primacy jurisdiction which is emanated from the traditional notions of State sovereignty didn't take into account the ongoing developments of international law in general and International Criminal Law in particular. As a result, the principle of primacy jurisdiction would broad either the possibility of impunity or double jeopardy of the accused. The principle of Concurrence Jurisdiction also has lots of drawbacks such as the problems in the distribution of suspects.

To overcome the pitfalls of primacy and concurrent jurisdictions, the principle of complementarity is allowing States to have primacy jurisdiction over the crimes and if States are unable or unwilling to discharge their primary responsibility, the Principle has set the mechanism to facilitate the stepping in of International Criminal Court or other criminal tribunals jurisdictions over international crimes which have been committed in the territories of member states.

\section{Acknowledgements}

I would like to thank Wondwossen Demissie (Ph.D.), Assistant Professor of Law at Addis Ababa University for his constructive comments. I also wish to acknowledge the two anonymous reviewers for their important remarks. I am solely responsible for any errors of fact or interpretation.

\section{Conflicts of Interest}

The author declares no conflicts of interest regarding the publication of this paper.

\section{References}

Brown, B. S. (1998). Primacy or Complementarity: Reconciling the Jurisdiction of National Courts and International Criminal Tribunals. Yale Journal of International Law, 383, 394-395.

Carter, L. E. (2010). The Principle of Complementarity and the International Criminal Court: The Role of Ne Bis in Idem. Santa Clara Journal of International Law, 8, 167.

El Zeidy, M. M. (2002). The Principle of Complementarity: A New Machinery to Implement International Criminal Law. Michigan Journal of International Law, 23, 870.

Fisha, A. (2009). Federalism Teaching Material (pp. 273-274). https://www.lawethiopia.com/images/teaching materials/federalism.pdf

Glory Nirmala, K., \& Zegeye, A. S. (2009). Criminal Law I (pp. 127-129). https://chilot.me/wp-content/uploads/2011/06/criminal-law-i.pdf

Jaffe, L. L. (1964). Primary Jurisdiction. Harvard Law Review, 77, 1037-1070. https://doi.org/10.2307/1339061 https://www.jstor.org/stable/1339061

Morris, M. H. (1997). The Trials of Concurrent Jurisdiction: The Case of Rwanda. Duke Journal of Comparative \& International Law, 7, 349-374. 
Newton, M. A. (2010). The Complementarity Conundrum: Are We Watching Evolution or Evisceration? Santa Clara Journal of International Law, 8, 115, 119-123.

Philippe, X. (2006). The Principles of Universal Jurisdiction and Complementarity: How Do the Two Principles Intermesh? International Review of the Red Cross, 88, 375-398. https://doi.org/10.1017/S1816383106000580 